\title{
Did COVID-19 lockdown brew “Amphan" into a super cyclone?
}

\author{
V. Vinoj* and D. Swain \\ School of Earth, Ocean and Climate Sciences \\ Indian Institute of Technology Bhubaneswar \\ *Email: vinoj@iitbbs.ac.in
}

\begin{abstract}
The world witnessed one of the largest lockdowns in the history of mankind ever, spread over months in an attempt to contain the contact spreading of the novel coronavirus induced COVID-19. As billions around the world stood witness to the staggered lockdown measures, a storm brewed up in the urns of the rather hot Bay of Bengal (BoB) in the Indian Ocean realm. When Thailand proposed the name "Amphan" (pronounced as "Um-pun" meaning 'the sky'), way back in 2004, little did they realize that it was the christening of the 1st super cyclone (Category-5 hurricane) of the century in this region and the strongest on the globe this year. At the peak, Amphan clocked wind speeds of 168 mph (Joint Typhoon Warning Center) with the pressure drop to $925 \mathrm{~h}$. Pa. What started as a depression in the southeast BoB at 00 UTC on 16th May 2020 developed into a Super Cyclone in less than 48 hours and finally made landfall in the evening hours of 20th May 2020 through the Sundarbans between West Bengal and Bangladesh. Did the impact of the COVID-19 induced lockdown drive an otherwise typical pre-monsoon tropical depression into a super cyclone?
\end{abstract}

\section{Global Warming and Tropical Cyclones}

Tropical cyclones are primarily fueled by the heat released by the oceans. Climate change and associated global warming have enabled significant accumulation of ocean heat content (OHC) across the globe increasing the frequency of intense tropical cyclones. The oceans are known to have absorbed more than $90 \%$ of all the excess heat trapped by the anthropogenic Green House Gas (GHG) emissions thereby rapidly increasing ocean surface temperatures ${ }^{1,2,3}$, favouring the genesis and intensification of cyclones. In fact 36 cyclones have been reported world over in the last four months of 2020 alone. Overall, there is seemingly a preferential increase in category $4 \& 5$ cyclones $^{4}$ throughout the globe in recent years.

\section{Bay of Bengal: The cyclonic hotbed}

The North Indian Ocean witnesses about $12 \%$ of the total number of global cyclones with an average of 5 to 6 of them forming in the BoB and the Arabian Sea (AS) every year ${ }^{5,6,7}$. With high population density, the coastal areas spread across India, Bangladesh and Myanmar are socially and economically vulnerable to damages owing to cyclones ${ }^{7}$. The Indo-Gangetic Plains (IGP) in South East Asia is among the most densely populated (with more than $60 \%$ of India's population) and highly polluted regions in the world ${ }^{8,9,10}$. These pollutants or particulate matter or atmospheric aerosols that can both scatter and absorb surfacereaching solar radiation ${ }^{11}$, are increasing at a rate of 2 to $3 \%$ per year ${ }^{12}$. The unique topography of the region, assisted by conducive wind patterns, transports most of these anthropogenic air pollutants into the $\mathrm{BoB}^{13}$. Therefore, heightened human activity leads to higher aerosol loading and hence cooling of the Bay. 
In addition, these aerosols are also known to increase cloud fraction by acting as cloud condensation nuclei, thus modifying their spread ${ }^{14}$.

\section{The Pandemic and the Lockdown: A catalyst?}
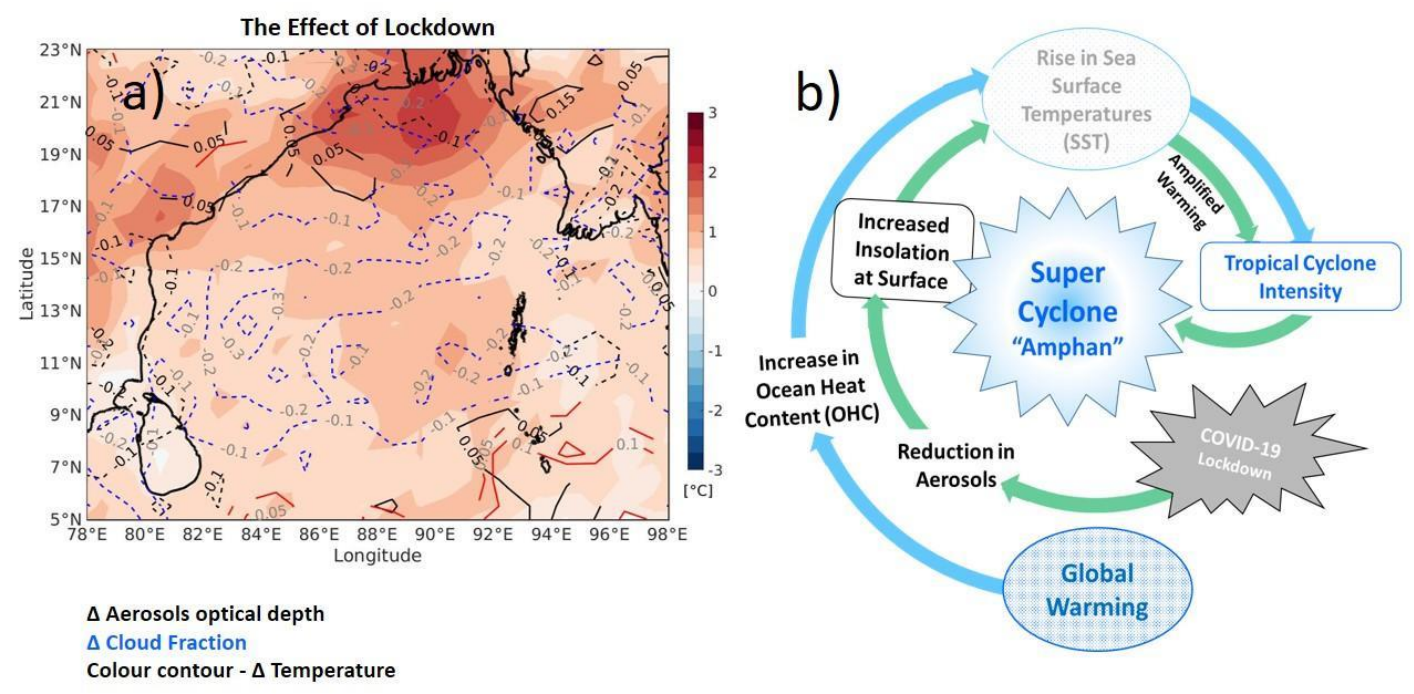

Figure. 1. a) The anomalies of sea surface temperature (color contour), aerosol optical depth (black line contour) and cloud fraction (blue line contour) during the lockdown and b) summary schematic on the possible mechanism of amplification of the strength of cyclone initiated by the lockdown.

The lockdown has rendered the atmosphere over the $\mathrm{BoB}$ relatively clean due to significant decline in anthropogenic activities and consequent aerosol loading and clouds by as much as $30 \%$ over the ocean (Table 1). Quite interestingly, the magnitude of this decline itself is much larger than the normal average aerosol loading over some of the developed nations. The combined decline of both aerosols and clouds could easily increase the sea surface temperature further compounding the climate change-related warming of the oceans (see also Table 1). The pre-existing high summer SST, climate change enhanced OHC, lockdown induced decline in aerosols \& clouds, are all perfect ingredients for genesis potential and subsequent intensification of any cyclonic activity.

Comparing the super cyclone "Amphan" (16th to 20th May 2020, $168 \mathrm{mph}, 925 \mathrm{hPa}$ ) (Category-5: > 156 mph) with a similar cyclone "Fani" (26th April to 5th May 2019, 155 mph, $932 \mathrm{hPa}$ ) (Category-4: 130-156 $\mathrm{mph}$ ) that formed in the same region and season last year suggests that Fani could have intensified easily to Category-5 if only such a large scale lockdown transpired last year which is also supported by a recent study ${ }^{15}$. Thus, seemingly disparate extreme events may compound our vulnerability to unforeseen disasters (Fig. 1) over certain regions and times demanding heightened disaster preparedness and consistent climate actions. Even though reduction in air pollution seem to have intensified the cyclone, it should not be inferred that mitigation of pollution would enhance cyclonic activity This could be a one off case where COVID19 induced lockdown and reduced pollution in sync with various favourable compounding factors may have led to intensification of the cyclone under consideration. This may likely be a once-in-lifetime case to have witnessed a cyclone being modulated by reduced air pollution and subsequent short-term effects. 
Table 1. The observed changes to the ocean and atmospheric parameters of relevance to cyclones over the Bay of Bengal due to global warming and COVID-19 lockdown (pre-lockdown minus lockdown of anomalies w.r.to climatology).

\begin{tabular}{|c|c|c|c|c|}
\hline \multirow[b]{2}{*}{ Parameter } & \multicolumn{2}{|c|}{ Ocean } & \multicolumn{2}{|c|}{ Atmosphere } \\
\hline & $\begin{array}{c}\text { Sea Surface } \\
\text { Temperature } \\
\text { (Skin) }\left({ }^{\circ} \mathbf{C}\right)\end{array}$ & $\begin{array}{l}\text { *Ocean Heat } \\
\text { Content700m } \\
\left(\times 10^{22} \mathrm{~J}\right)\end{array}$ & $\begin{array}{c}\text { Aerosol Optical } \\
\text { Depth* }^{*}\end{array}$ & $\begin{array}{c}\text { Cloud } \\
\text { Fraction* }(\%)\end{array}$ \\
\hline $\begin{array}{l}\text { Change } \\
\text { during } \\
\text { Lockdown }\end{array}$ & +1 to 2 & +0.1347 & $-0.1(25$ to $30 \%)$ & -30.0 \\
\hline Data Sources & AIRS & NOAA-NODC & MODIS Terra/Aqua & $\begin{array}{c}\text { MODIS } \\
\text { Terra/Aqua }\end{array}$ \\
\hline
\end{tabular}

*absolute difference with respect to 2019

\section{Acknowledgement}

The authors wish to acknowledge the various data sources that have been used in this work including NASA Giovanni data archive. Technical discussions with Dr. Kiranmayi Landu, faculty at School of Earth, Ocean \& Climate Sciences (SEOCS), IIT Bhubaneswar is gratefully acknowledged. Sincere thanks are also due to Mr. S. K. Pandey and Mr. S. K. Ghose, research scholars at SEOCS for their assistance with preliminary data processing. 


\section{References}

1. Rhein, M., Rintoul, S. R., Aoki, S., Campos, E., Chambers, D., Feely, R. A., Gulev, S., Johnson, G. C., Josey, S. A., Kostianoy, A., Mauritzen, C., Roemmich, D., Talley L. D. \& Wang, F. Observations: Ocean. Climate Change 2013: The Physical Science Basis. Contribution of Working Group I to the Fifth Assessment Report of the Intergovernmental Panel on Climate Change, T. F. Stocker, D. Qin, G.-K. Plattner, M. Tignor, S.K. Allen, J. Boschung, A. Nauels, Y. Xia, V. Bex and P.M. Midgley Eds., Cambridge University Press, Cambridge, UK, New York, NY, USA (2013).

2. Abram, N., Gattuso, J.-P., Prakash, A., Cheng, L., Chidichimo, M. P., Crate, S., Enomoto, H., Garschagen, M., Gruber, N., Harper, S., Holland, E., Kudela, R. M., Rice, J., Steffen, K. \& von Schuckmann, K. Framing and Context of the Report. In: IPCC Special Report on the Ocean and Cryosphere in a Changing Climate, H.-O. Pörtner, D.C. Roberts, V. Masson-Delmotte, P. Zhai, M. Tignor, E. Poloczanska, K. Mintenbeck, A. Alegría, M. Nicolai, A. Okem, J. Petzold, B. Rama, N. M. Weyer Eds. (2019) (in press)

3. Cheng, Li-J, Abraham, A., Zhu, J, Trenberth, K. E., Fasullo, J., Boyer, T., Locarnini, R., Zhang, B., Yu, F., Wan, L., Chen, X., Song, X., Liu, Y. \& Mann, M. E. Record-setting ocean warmth continued in 2019. Advances in Atmospheric Sciences, 37, 137-142 (2020).

4. Klotzbach, P. J. \& Landsea, C. W.: Extremely intense hurricanes: Revisiting Webster et al. (2005) after 10 years. Journal of Climate, 28, 7621-7629 (2015).

5. Singh, O. P., Khan, T. M. A. \& Rahman, S. Has the frequency of intense tropical cyclones increased in the North Indian Ocean?. Current Science, 80 (4), 575-580 (2001).

6. Mohanty, U. C., Osuri, K. K., Tallapragada, V., Marks, F. D., Pattanayak, S., Mohapatra, M., Rathore, L. S., Gopalkrishnan, S. G. \& Nioyogi, D. A great escape from the Bay of Bengal "Super Sapphire-Phailin" tropical cyclone: a case of improved weather forecast and societal response for disaster mitigation. Earth Interactions, 19 (17), 47907-2054, doi: http://dx.doi.org/10.1175/EI-D14-0032.1 (2015).

7. Jangir, B., Swain, D. \& Ghose, S. K. Influence of Eddies and Tropical Cyclone Heat Potential on intensity changes of Tropical Cyclones in the North Indian Ocean. Advances in Space Research, https://doi.org/10.1016/j.asr.2020.01.011 (2020).

8. Akimoto, H. Global Air Quality and Pollution. Science, 302 (5651), 1716-1719, DOI: 10.1126/science.1092666 (2003)

9. Ghude, S. D., Chate, D. M., Jena, C., Beig, G., Kumar, R., Barth, M. C., Pfister, G. G., Fadnavis, S. \& Pithani, P. Premature mortality in India due to PM2.5 and ozone exposure. Geophysical Research Letters, 43(9), 4650-4658, https://doi.org/10.1002/2016GL068949 (2016).

10. Greenstone, M., Nilekani, J., Pande, R., Ryan, N., Sudarshan, A. \& Sugathan, A. Lower pollution, longer lives. Economic and Political Weekly, 8, 40-46 (2015). 
11. Vinoj, V., Babu, S. S., Satheesh, S. K., Moorthy, K. K. \& Kaufman, Y. J. Radiative forcing by aerosols over the Bay of Bengal region derived from ship-borne, island-based, and satellite (Moderate-Resolution Imaging Spectroradiometer) observations. Journal of Geophysical Research, 109 (D5), Art. No. D05203. doi:10.1029/2003JD004329 (2004).

12. Moorthy, K. K., Babu, S. S., Manoj, M. R. \& Satheesh, S. K. Buildup of aerosols over the Indian Region. Geophysical Research Letters, 40, 1011- 1014, doi:10.1029/2012GL054876 (2013).

13. Nair, V. S., Krishna Moorthy, K., Alappattu, D. P., Kunhikrishnan, P. K., George, S., Nair, P. R., Babu, S. S., Abish, B., Satheesh, S. K., Tripathi, S., Niranjan, K., Madhavan, B. L., Srikant, V., Dutt, C. B. S., Badarinath, K. V. S. \& Reddy, R. R. Winter time aerosol characteristics over the Indo-Gangetic Plain (IGP): Impacts of local boundary layer processes and long-range transport. Journal of Geophysical Research, 112, D13205. 10.1029/2006JD008099 (2007).

14. Pandey, S. K., Vinoj, V. \& Panwar, A. The short-term variability of aerosol and its impact on cloud properties and radiative effect over the Indo-Gangetic Plain. Atmospheric Pollution Research, 11(3), 630-638, https://doi.org/10.1016/j.apr.2019.12.017 (2020).

15. Lin Zhao, S.-Y. Simon Wang, Emily Becker, Jin-Ho Yoon and Avik Mukherjee, Cyclone Fani: The tug-of-war between regional warming and anthropogenic aerosol effects, Environmental Research Letters (Accepted Manuscript) (2020). 